\title{
Investigating the accountability of Transnational Armed Groups under International Law for armed attacks
}

\author{
Anna Marie Brennan
}

Department and Faculty of Law, UCC

\section{Introduction}

According to the National Counterterrorism Centre in the United States, there were approximately 11,000 attacks carried out by Transnational Armed Groups worldwide in 2009. A Transnational Armed Group can be described as a non-state armed actor which operates beyond the territorial borders of a single state and carries out serious and violent acts intended to cause fear, death, serious bodily injury and property damage to a person, group or general population in order to force a government or international organisation to perform or refrain from performing a particular act. An example of a Transnational Armed Group is Al-Qaeda. According to the Program on Humanitarian Policy and Conflict Research (HPCR) at Harvard University, other examples of Transnational Armed Groups include Jemaah Islamiyah and the Palestine Liberation Organisation. However, these particular Transnational Armed Groups are more limited in geographical scope and vary in organisation and objectives. According to HPCR, Al Qaeda is the only Transnational Armed Group operating on such a wide geographical basis with training grounds in Pakistan, Afghanistan and Uganda. In addition, it is noted that $\mathrm{Al}$ Qaeda has also proven itself to be global in outlook by carrying out armed attacks in locations such as Madrid, London, Bali, Karachi and New York.

In recent years, states have changed from law enforcement to an armed engagement in their methods of handling the threats posed by Transnational Armed Groups. Domestic law enforcement has proven to be an ineffective tool in deterring attacks by Transnational Armed Groups because it has not been able to keep up with the new methods such as Improvised Explosive Devices (IED) continuously developed by Transnational Armed Groups to carry out attacks against civilians. Many academics consider these violent acts by Transnational Armed Groups to be an armed conflict to which International Humanitarian Law applies. Therefore, it is necessary to consider how Transnational Armed Groups can be held accountable under International Law for attacking civilians if such acts constitute an armed conflict. 


\section{The rationale for holding Transnational Armed Groups accountable under international law as opposed to domestic law}

Although there are many rationales for holding Transnational Armed Groups accountable under International Law for violent attacks, the most convincing rationale is that domestic legal systems are not the most suitable forum for addressing the violent acts of Transnational Armed Groups. The criminal justice system is based on the principle that criminal activity can be prevented or controlled by deterrence. Craig Allen, who is the Judson Falknor Professor of Law at the University of Washington in the United States, notes that this deterrence takes two forms. According to him, the first form is specific deterrence, which refers to the practice, usually through imprisonment, of disabling a particular actor from committing future crimes.' The second form is general deterrence which describes the 'public effect' of such punishment in deterring others from carrying out crimes. According to Professor Allen, general deterrence assumes that a rational actor will cease criminal behaviour if the potential cost as discounted by the likelihood of being apprehended and tried for the crime is too high. Professor Allen also notes that the general-deterrence approach to criminal justice depends on the 'choice theory' of criminal behaviour. Choice theory views a person's decision to take part in criminal activity as a rational choice established on the apparent consequences of taking part or not taking part in criminal behaviour. However, the deterrence approach tends to break down with regard to Transnational Armed Groups operating in locations beyond the criminal jurisdiction of nations. In addition, it is important to emphasise that the domestic criminal justice system is by nature reactive in that the system in general endeavours to identify persons who have already committed crimes and to then gather the evidence necessary for their indictment, prosecution and conviction.'

Nevertheless, it is important to point out that there are numerous insurmountable challenges to prosecuting members of Transnational Armed Groups within the domestic criminal justice system. Firstly, assembling the necessary evidence for achieving a conviction from locations outside the state's jurisdiction can be obtained only with the cooperation of the host state. It can be readily observed that not all states will be willing to cooperate, and some states may not be able to offer any assistance. Secondly, it is argued that exercising jurisdiction over members of Transnational Armed Groups such as Al-Qaeda can be problematic in that it can be extremely difficult to secure the extradition of a suspect due to the non-existence of an extradition treaty. A state may also refuse to extradite any person to a state where the death penalty might be imposed if the person is convicted. In addition, the security precautions necessary for judges, prosecutors, witnesses and jurors in trials of member of Transnational Armed Groups offer a perspective on the financial costs of prosecuting members of Transnational Armed Groups suspected of planning and carrying out violent armed attacks. During trial, certain evidence against the accused 
will be classified or will require summoning witnesses from abroad and members of state armed forces and law enforcement agencies to give evidence at trial. The prospect of disclosing classified information to members of Transnational Armed Groups for use in their defence at trial highlights the national security implications of prosecuting members of Transnational Armed Groups in the domestic legal system. Therefore, it needs to be considered whether international criminal justice would be a better legal mechanism for holding members of Transnational Armed Groups accountable for armed attacks.

\section{The applicability of the Geneva conventions to Transnational Armed Groups}

In considering whether Transnational Armed Groups can be held accountable under International Criminal Law as opposed to domestic criminal law, it is first necessary to examine whether the violent sporadic attacks they perpetrate constitute an armed conflict within the meaning of the Geneva Conventions. The Geneva Conventions and their Additional Protocols are the principal legislative instruments of International Humanitarian Law (IHL), the branch of international law that governs the conduct of armed conflict and seeks to restrict its consequences. In particular, the Geneva Conventions seek to protect those persons who are not taking part in the hostilities, for example civilians and health care workers, and those who are no longer participating in the hostilities, such as prisoners of war and the sick and wounded. Common Article 2 of the Geneva Conventions states that the Geneva Conventions are applicable to armed conflicts of an international nature. Therefore, Common Article 2 only applies to armed conflict between states and not to violent attacks by Transnational Armed Groups. On the other hand, Common Article 3 of the Geneva Conventions, which applies to armed conflict occurring within the territory of a state between state armed forces and dissident armed forces, may also regulate attacks by Transnational Armed Groups. Two requirements in particular define the scope of application of Common Article 3:

$\square$ the existence of an armed conflict; and

that it is a non-international armed conflict.

However, characterising attacks by Transnational Armed Groups as an armed conflict within the meaning of Common Article 3 raises major policy questions. First of all, ascribing 'belligerent' or 'combatant' status to members of Transnational Armed Groups might invest members of such groups with rights and privileges under International Humanitarian Law. Secondly, the classification of attacks by Transnational Armed Groups as an armed conflict may also symbolically aggrandise the Transnational Armed Group by suggesting that states consider them much more than a sinister criminal organisation. Lastly, categorising attacks by Transnational Armed Groups as an armed conflict could also im- 
munise members of such armed groups from prosecution for proportional attacks directed against military targets. As a result of these issues, it is difficult to categorise attacks by Transnational Armed Groups under either traditional perceptions of war or contemporary ideas of armed conflict. Nevertheless, the attacks do exhibit several characteristics of armed conflict including their purpose, coordination and intensity.

The question of whether Common Article 3 of the Geneva Conventions regulates armed attacks by Transnational Armed Groups still remains. The text of Common Article 3 provides very little guidance on the issue. According to Professor Jinks, Common Article 3 is only helpful in determining the type of armed conflicts it does not regulate by identifying its field of application as armed conflict not of an international nature. Jurisprudence of the International Criminal Tribunal for the Former Yugoslavia (ICTY) has arguably clarified the definition of armed conflict in IHL. In particular, the ICTY Appeals Chamber in the case, Prosecutor v. Tadic (Tadic), concluded that:

[A]rmed conflict exists whenever there is a resort to armed force between States and protracted armed violence between ... such groups within a State. International humanitarian law applies from the initiation of such armed conflicts and extends beyond the cessation of hostilities until a general conclusion of peace is reached; or, in the case of internal armed conflicts, a peaceful settlement is achieved. Until that moment, international humanitarian law continues to apply in the whole of the territory of the warring States or, in the case of internal conflicts, the whole territory under the control of a party, whether or not actual combat takes place.

Two features of this definition clarify the meaning of 'armed conflict' under International Law. First of all, the term suggests that an armed conflict exists only if the armed group controls a segment of the state's territory. Secondly, the term categorises internal hostilities as an armed conflict only if the violence is protracted. Professor Jinks contends that both requirements would limit the conditions under which Common Article 3 applies. Even though the definition laid down by the ICTY is persuasive, a careful reading of the Tribunal's reasoning makes clear that it does not restrict the scope of application of Common Article 3 to Transnational Armed Groups.

The Tribunal's definition does not require that armed groups have control over territory within the state. The Tribunal defines the circumstances in which International Humanitarian Law applies by carefully analysing its general scope of application, the temporal scope of application and the territorial scope of application. Professor Jinks notes that by defining the territorial field of application for non-international armed conflict the ICTY confirms that IHL is applicable in territory that is no longer under the control of the state and in the whole of that territory.

According to Professor Jinks, the 'protracted' armed violence requirement does not limit the application of IHL in any considerable way. The conclusion reached by the ICTY Appeals Chamber in Tadic indicates that most instances of internal violence would satisfy this requirement. Whether the internal violence is protracted, is determined by reference 
to the entire time period of the armed hostilities from the initiation to the cessation of the hostilities. Moreover, IHL applies to all acts committed during an armed conflict even if the act was committed before the point at which the 'protracted' threshold was crossed. To be precise, the 'protracted' requirement does not exclude acts committed in the early stages of a non-international armed conflict. The 'protracted' armed violence requirement can be best appreciated as little more than a reiteration of the rule excluding isolated and sporadic acts of violence from the scope of IHL. Furthermore, the jurisprudence of the International Criminal Tribunal for Rwanda established that armed violence over a period of a few months meets the 'protracted' requirement and, because of the level and intensity of the armed violence, it constituted an armed conflict within the meaning of Common Article 3.

\section{Conclusion}

In conclusion, the intensity, coordination, and pattern of attacks by Transnational Armed Groups against the United States and other states make clear that attacks by Transnational Armed Groups are not simply isolated and sporadic acts of violence but instead constitute an armed conflict within the meaning of Common Article 3. Attacks by Transnational Armed Groups have involved the coordinated use of force and have demonstrated their capability to operate globally even against military and diplomatic targets. It is clear that the organisational capacity of Transnational Armed Groups such as the Palestine Liberation Front and Al Qaeda distinguishes them from 'mere bandits' in that they possess the de facto capability to carry out sustained armed attacks against states.

Anna Marie Brennan is a PhD Candidate in the Department and Faculty of Law under the supervision of Dr. Siobhan Wills and Dr. Fiona Donson. The author wishes to acknowledge funding from the Department and Faculty of Law, University College Cork. 